\title{
Validitas Model "Produksi" Sebagai Alternatif Model Pembelajaran Untuk Mendukung Kurikulum 2013
}

\author{
Wirawan Fadly \\ Institut Agama Islam Negeri Ponorogo, Indonesia \\ e-mail: wira1fadly@iainponorogo.ac.id
}

\begin{abstract}
.
The 2013 curriculum (K13) recommends teachers / educators to use a learning approach oriented to project-based learning (Permendikbud 65 of 2013), and for skills that need to be given attention to 21 st century learning according to $\mathrm{K} 13$ one of them is communication skills. The project-based learning model developed needs to be adjusted to the demands of the 21st and K13 century learning, namely a project-based physics learning model that is oriented towards communication skills, so that innovation is made to develop project-based learning by the name of PRODUCTION learning model. The purpose of this study was to determine the quality of the PRODUCTION model and its supporting devices. The research method to see the validity of the product developed is through quantitative research using a limited type of survey research. Survey was conducted to obtain quality information from the product being developed, and was limited to related experts. Analysis of validation results included validation of learning model construction and content validation in the form of the supporting devices were analyzed using quantitative descriptive analysis. Assessment of the validity of the PRODUCTION learning model and its supporting devices using the model validation instrument and learning tools. Based on the expert evaluation, it can be concluded that the model that has been developed (PRODUCTION model) is constructively valid and feasible to be implemented in learning with scientific approach characteristics in accordance with K13 recommendations, and the supporting devices are RPP, LKPD, LE and LP in a valid and feasible content implemented in learning physics, supporting project activities and solving physical problems, and being able to develop one of the 21 st century skills of science communication skills.
\end{abstract}

Keywords : Validity, PRODUCTION Learning Model.

\begin{abstract}
ABSTRAK.
Kurikulum 2013 (K13) merekomendasikan guru/pendidik menggunakan pendekatan pembelajaran yang diorientasikan pada pembelajaran berbasis proyek (Permendikbud 65 Tahun 2013), dan untuk keterampilan yang perlu diberikan perhatian pada pembelajaran abad 21 sesuai K13 salah satu di antaranya adalah keterampilan berkomunikasi. Model pembelajaran berbasis proyek yang dikembangkan perlu disesuaikan dengan tuntutan pembelajaran abad 21 dan K13 tersebut, yaitu model pembelajaran fisika berbasis proyek yang diorientasikan pada keterampilan berkomunikasi, sehingga dilakukan inovasi mengembangkan pembelajaran berbasis proyek dengan nama model pembelajaran PRODUKSI. Tujuan penelitian ini adalah untuk menentukan kualitas model PRODUKSI beserta perangkat pendukungnya. Metode penelitian untuk melihat validitas produk hasil pengembangan adalah melalui penelitian kuantitatif dengan menggunakan jenis penelitian survey terbatas.Survey dilakukan untuk memperoleh informasi kualitas dari produk yang dikembangkan, dan bersifat terbatas bagi ahli terkait.Analisis data hasil validasi meliputi validasi konstruksi model pembelajaran dan validasi konten berupa perangkat pendukungnya yang dianalisis menggunakan analisis deskriptif kuantitatif. Penilaian validitas model pembelajaran PRODUKSI dan perangkat pendukungnya menggunakan instrumen validasi model dan perangkat pembelajaran. Berdasarkan hasil penilaian ahli dapat disimpulkan jika model yang telah dikembangkan (model PRODUKSI) secara konstruksi valid dan layak diimplementasikan dalam pembelajaran yang berkarakteristik scientific approach sesuai dengan rekomendasi K13, dan perangkat pendukungnya berupa
\end{abstract}


RPP, LKPD, LE dan LP secara konten valid dan layak diimplementasikan dalam pembelajaran fisika, mendukung aktivitas proyek serta penyelesaian masalah fisika, dan mampu mengembangkan salah satu keterampilan abad 21 yaitu keterampilan berkomunikasi sains.

Kata kunci: Validitas, Model Pembelajaran PRODUKSI.

\section{PENDAHULUAN}

Abad 21 ditandai dengan adanya perubahan-perubahan di segala bidang, salah satunya adalah di bidang pendidikan. Perubahan di bidang pendidikan dapat diamati dengan adanya perubahan kurikulum di awal tahun 2000-an hingga sekarang. Praktis ada tiga kurikulum dengan filosofi berbeda yang telah diterapkan dalam sistem pendidikan di Indonesia yaitu dimulai dari KBK, KTSP dan sekarang Kurikulum 2013 (K13). Kesamaan yang paling fundamental dari ke tiga kurikulum tersebut adalah sama-sama berbasis kompetensi dengan mengacu pada sistem penilaian acuan kriteria, namun perbedaannya dapat dilihat dari proses pembelajarannya dimana KBK lebih menekankan pada pembelajaran yang diorientasikan pada hasil belajar dan keberagaman, KTSP yang merupakan perbaikan dari KBK lebih ditekankan pada otonomi belajar, sedangkan K13 diorientasikan pada proses belajar melalui pendekatan scientifi approach. Perubahan kurikulum yang terjadi di bidang pendidikan ini merupakan upaya pemerintah untuk merespon adanya perubahan sosial, perkembangan IPTEK, dan berkembangnya penelitian di dunia pendidikan.

Respons yang dilakukan pemerintah untuk melakukan penyesuaian kurikulum juga harus diimbangi dengan berbagai inovasi pembelajaran.Hal ini karena kurikulum merupakan pedoman yang dijadikan acuan dalam perencanaan, pelaksanaan, dan evaluasi pembelajaran.Sehingga dengan adanya perubahan kurikulum maka inovasi-inovasi pembelajaran yang berkaitan dengan ketiga unsur belajar tersebut dapat berjalan dengan baik seiring tuntutan zaman. K13 telah berjalan sekitar lima tahun, namun masih banyak satuan pendidikan yang belum menerapkan secara menyeluruh. Berbagai kendala muncul pada saat awal-awal pelaksanaan kurikulum, salah satunya yaitu, banyaknya guru yang sulit menerapkan proses pendekatan ilmiah seperti pembelajaran berbasis proyek.

K13 merekomendasikan guru/pendidik menggunakan pendekatan pembelajaran yang diorientasikan pada pembelajaran berbasis proyek (Permendikbud 65 Tahun 2013), dan untuk keterampilan yang perlu diberikan perhatian pada pembelajaran abad 21 salah satu di antaranya adalah keterampilan berkomunikasi. Hal ini karena apabila terjadi komunikasi yang efektif dengan masyarakat yang lebih luas maka dapat melatihkan peran aktif masyarakat dalam kegiatan ilmiah, sikap ilmiah dan memungkinkan berbagi wawasan keilmuan (Treise et al., 2002).Pentingnya komunikasi dalam pembelajaran dijadikan sebagai salah satu aspek yang dikembangkan untuk mendukung pembelajaran abad 21 dan kurikulum terbaru saat ini yaitu K13. Filosofi dari K13 adalah pendidikan untuk membangun kehidupan masa kini dan masa depan yang lebih baik di mana perlu menekankan pada kemampuan intelektual, kemampuan berkomunikasi, sikap sosial, kepedulian, dan berpartisipasi untuk membangun kehidupan masyarakat dan bangsa yang lebih baik. Sehingga mengelola komunikasi yang efektif sangatlah penting karena dapat mengembangkan potensi peserta didik untuk mampu berpikir reflektif bagi penyelesaian masalah di masyarakat.

Pembelajaran berbasis proyek memiliki beberapa kelebihan dibanding pembelajaran lainnya, karena dapat membantu siswa untuk menghasilkan karya konstektual, mengembangkan kemampuan berkolaborasi, membuat keputusan/inisiatif, dan mengatasi 
masalah kompleks (Yalcin et al., 2009).Melalui pembelajaran berbasis proyek memungkinkan siswa memperluas wawasan pengetahuan dari suatu mata pelajaran tertentu.Diharapkan pengetahuan yang diperoleh menjadi lebih bermakna, kegiatan pembelajaran menjadi lebih menarik, siswa lebih aktif dan terampil dalam mengomunikasikan pengetahuan.Hal ini menunjukkan bahwa pembelajaran berbasis proyek merupakan pendekatan yang adaptif dan dinamis untuk memfasilitiasi multiskill.Berdasarkan karakteristik tersebut maka ada ruang untuk melakukan penelitian pengembangan pembelajaran berbasis proyek dalam memfasilitasi keterampilan tertentu.

Model pembelajaran berbasis proyek yang dikembangkan perlu disesuaikan dengan tuntutan pembelajaran abad 21 dan K13, yaitu model pembelajaran fisika berbasis proyek yang diorientasikan pada keterampilan berkomunikasi, sehingga dilakukan inovasi mengembangkan pembelajaran berbasis proyek dengan nama model pembelajaran PRODUKSI. Model PRODUKSI diharapkan dapat menjadi solusi untuk mengembangkan keterampilan berkomunikasi sains serta mewujudkan belajar yang komunikatif dan menyenangkan. Model pembelajaran yang baik dan layak digunakan harus memiliki kriteria valid, praktis dan efektif, namun tujuan penelitian pada artikel ini akan lebih ditekankan untuk mengetahui tingkat validitas model pembelajaran PRODUKSI sebagai solusi alternatif model pembelajaran untuk mendukung implementasi K13.

\section{METODOLOGI}

Metode penelitian untuk melihat validitas produk hasil pengembangan adalah melalui penelitian kuantitatif dengan menggunakan jenis penelitian survey terbatas.Survey dilakukan untuk memperoleh informasi kualitas dari produk yang dikembangkan, dan bersifat terbatas bagi ahli terkait.Karena validasi ini merupakan bagian awal dari penelitian pengembangan, maka produk yang dikembangkan belum bersifat final, karena perlu diuji secara empiris untuk melihat kepraktisan dan efektivitasnya.Pada kegiatan validasi ini hanya difokuskan untuk melihat kualitas konstruksi dan konten dari produk yang telah dikembangkan sebelum diterapkan. Produk yang dikembangkan diberi nama Model Pembelajaran PRODUKSI beserta perangkat pendukungnya. Kualitas konten dan konstruksi model pembelajaran PRODUKSI beserta perangkat pendukungnya tersebut dapat diketahui dengan cara mengumpulkan data melalui pemberian kuesioner kepada tim ahli atau yang disebut sebagai tim validator untuk mendapatkan penilaian. Pemilihan validator dilakukan secara purpossive sampling berdasarkan keahlian yang relevan dengan produk yang dikembangkan.Agar data yang dihasilkan obyektif, maka validator yang terlibat diwakili oleh beberapa ahli yang berasal dari kampus berbeda. Validator yang terlibat terdiri dari lima orang ahli dari berbagai bidang pendidikan, yaitu tiga dosen di bidang pendidikan sains/IPA dari dan UNESA Surabaya dan UNY Yogyakarta, satu ahli teknologi pembelajaran dari UM Malang, satu ahli bahasa dari UINSA Surabaya, dan satu ahli lagi di bidang keilmuan Fisika dari ITS Surabaya.

Validasi model pembelajaran PRODUKSI dilakukan untuk meninjau tingkat kevalidan berdasarkan konstuksinya yang terdiri dari konstruksi dalam mengembangkan fase (fase-fase pembelajaran), konstruksi sistem sosialnya, konstruksi prinsip pengelolaan/reaksi, dan untuk melihat dampak instruksional dan pengiringnya. Model pembelajaran PRODUKSI dikatakan valid apabila memperoleh kirteria minimal baik.Sedangkan validitas perangkat perangkat pendukungnya ditinjau berdasarkan konten RPP, LKPD, dan Lembar Evaluasi \& Penilaian dikatakan valid apabila memperoleh kirteria minimal baik. 
Penilaian validitas model pembelajaran PRODUKSI dan perangkat pendukungnya menggunakan lembar validasi model dan perangkat pembelajaran. Lembar validasi digunakan sebagai acuan untuk menilai kelayakan format dan substansi komponen model pembelajaran yang telah dikembangkan. Data yang diperoleh akan dianalisis sesuai dengan karakteristik data. Analisis data hasil validasi meliputi validasi model pembelajaran dan validasi perangkat pendukungnya dianalisis menggunakan analisis deskriptif kualitatif, yaitu dengan merata-rata skor yang diperoleh dari para validator.Produk dinyatakan valid jika minimal memperoleh skor minimal 2.75 (Adaptasi Ratumanan \& Laurens, 2006).Untuk mendukung nilai validitas yang diberikan oleh validator, dilakukan pengecekan pula nilai konsistensi data hasil penilaian dengan melihat reliabilitasnya.Reliabilitas instrumen validasi ditentukan berdasarkan data dari pengamat.Tingkat reliabilitas penilaian dihitung menggunakan Percentage of agreements (R). Hasil pengamatan dikatakan reliabel bila reliabilitas yang diperoleh $\geq 0$, 75.Setelah validitasnya diketahui maka untuk membuat simpulan layak dan tidaknya produk yang dikembangkan dapat digunakan, maka dapat dihitung dengan menggunakan content validity ratio $(C V R)$, maka dihitung dengan mengggunakan kriteria dari Lawshe (Cohen \& Swerdik, 2010), di mana sekurang-kurangnya 4 orang dari 5 orang ahli telah menyatakan setuju dan layak dengan instrumen tersebut untuk digunakan sebagai alat pengumpul data pada penelitian, atau dengan validitas minimum 0,60 .

\section{HASIL DAN PEMBAHASAN}

Pengembangan model pembelajaran dilakukan melalui berbagai macam kajian yang meliputi kajian teoritis dan empiris.Kajian teoritis dilakukan dengan mengkaji referensi yang berkaitan dengan teori belajar, teori yang berkaitan dengan pembelajaran berbasis proyek, teori komunikasi dan perspektif teoritis lainnya yang relevan dengan tujuan penelitian.Kajian empiris ini merupakan bentuk dukungan dalam mengembangkan model yang diperoleh dari hasil penelitian para ahli. Berdasarkan penelitian para ahli akan diketahui karakteristik, keunggulan dan keterbatasan serta efek dari implementasi model pembelajaran berbasis proyek yang akan dikembangkan. Setelah model pembelajaran dikembangkan, kemudian dilakukan kegiatan FGD, sedangkan validasi dilakukan untuk mengetahui kualitas model pembelajaran beserta perangkat pendukung yang dikembangkan dengan melibatkan para ahli di berbagai bidang sebagai validator. Model pembelajaran yang dikembangkan di samping dikaji melalui forum FGD, juga dilakukan validasi dan telaah model pembelajaran oleh lima ahli, yaitu tiga orang ahli di bidang Pendidikan Sains/IPA, satu orang ahli teknologi Pembelajaran dan dan satu orang ahli Fisika.

Sebelum dibahas tentang hasil validasi, perlu dibahas konstruksi teoritis penyusunan model pembelajaran yang dikembangkan sebagai bahan informasi dan juga pijakan untuk mengembangkan perangkat pendukungnya.Penyusunan fase-fase pembelajaran disesuaikan dengan teori perkembangan intelektual Piaget dan Glasser managemet class, hal ini dilakukan agar fase yang disusun sesuai dengan tahap perkembangan intelektual siswa serta efektif dan sistematis sesuai dengan kebutuhan.Peran teori ini adalah, untuk membuat fase pembelajaran lebih sistematis dan logis. Berdasarkan kajian teoritis, hasil pengembangan model pembelajaran dapat ditunjukkan pada Gambar berikut ini. 


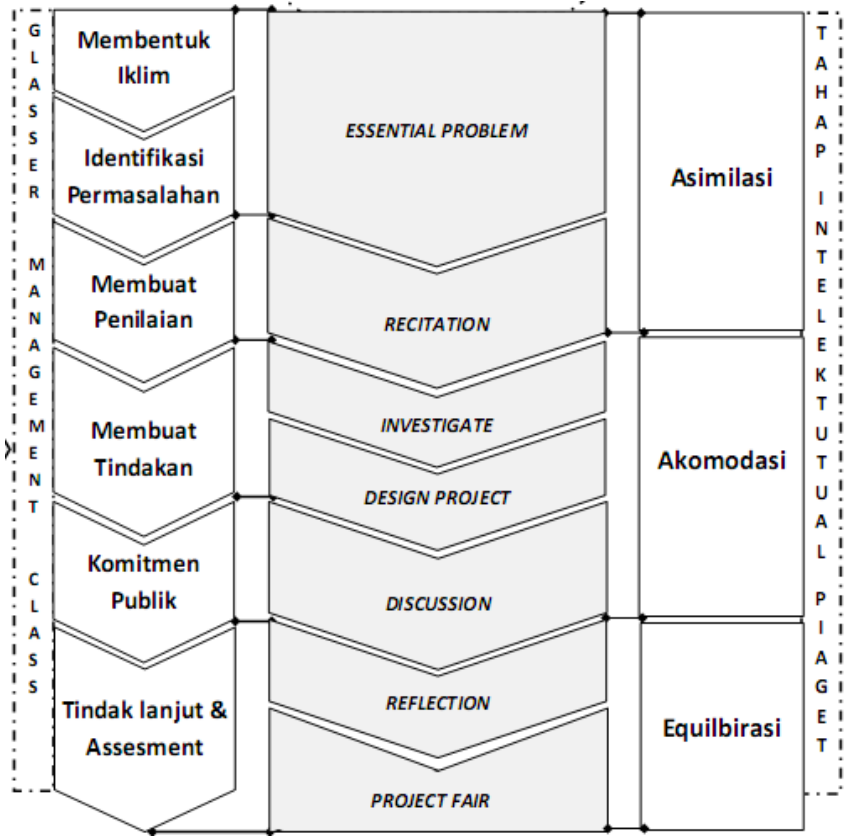

Gambar 1. Model Pembelajaran yang Dikembangkan

Model pembelajaran proyek yang dikembangkan dinamakan Model PRODUKSI yang merupakan akronim dari "pembelajaran berbasis proyek yang diorientasikan menggunakan keterampilan berkomunikasi”. Model yang dikembangkan terdiri dari tujuh kegiatan utama yang meliputi: 1) essential problem, 2) recitation, 3) investigate, 4) design plan project, 5) discussin, 6) reflection, dan 7) project fair.

Essential problem: pada tahap ini fase pembelajaran diorientasikan pada pembentukan iklim belajar yang problematis melalui pemberian masalah. Pembelajaran dimulai dengan menyajikan masalah esensial, yaitu dengan menunjukkan berbagai fenomena fisika sesuai dengan realitas kehidupan sehari-hari. Masalah yang diberikan adalah permasalahan yang menantang dan dideskripsikan dengan jelas melalui cara non evaluatif. Berdasarkan hasil penelitian menunjukkan bahwa penyajian masalah dapat menantang siswa untuk berpikir.Penyajian masalah esensial tersebut, merupakan upaya untuk memunculkan konsepsi awal siswa (Gallagher et al., 1995). Sebagaimana pendapat Woolfolk (2009) yang menyatakan bahwa materi yang dielaborasi (dalam bentuk masalah) ketika pertama kali dipelajari akan lebih mudah diingat kembali nantinya.

Konsepsi awal ini dapat dibangun dengan cara meminta siswa untuk menuliskan apa saja yang telah diketahui siswa pada topik pembicaraan atau dengan menjawab beberapa pertanyaan yang diberikan guru. Proses belajar akan terjadi jika siswa dihadapkan masalah dalam kehidupan dunia nyata untuk dipecahkan, sehingga siswa akan membentuk pengetahuan baru melalui langkah analisis terhadap pengetahuan yang diperolehnya (Arends, 2007). Berdasarkan pendapat tersebut maka tujuan dari tahapan ini untuk memusatkan perhatian siswa dengan mengaitkan topik yang dipelajari dengan fenomena disekitar siswa.Aktivitas pada tahap ini lebih menekankan pada keterampilan berkomunikasi sains yaitu dalam melakukan observasi fenomena.

Recitation: pada tahap ini terjadi pertukaran verbal berupa tanya-jawab guru dan siswa dalam memahami informasi. Kemampuan berkomunikasi yang terlibat pada tahap ini adalah presentasi gagasan dan representasi informasi.Tahap ini guru berkomunikasi dengan melontarkan serangkaian pertanyaan yang berbentuk diskrepansi (ketidaksesuaian) kepada 
siswa.Vygotsky (dalam Arends, 2007) menyatakan bahwa pemahaman siswa berkembang ketika individu menghadapi pengalaman baru yang membingungkan dan ketika mereka berusaha mengatasi diskrepansi yang ditimbulkan oleh pengalaman-pengalaman tersebut. Berdasarkan hal tersebut maka pemahaman siswa dapat diperiksa dengan meminta siswa untuk merespons, kemudian memberikan umpan-balik berupa uji coba dan dilanjutkan dengan pemberian penugasan yang menantang.

Pola dasar recitation adalah kegiatan pembelajaran di mana siswa dalam pengaturan kelas diberi pertanyaan atas pembelajaran yang mereka dapatkan dengan format tanya jawab. Tujuan dari tahap ini adalah melatih siswa menyelesaikan masalah dengan mengalami langkah-langkah pembentukan konsep secara ilmiah, seperti siswa diberikan sejumlah pertanyaan yang perlu dibahas dan dicari penjelasannya melalui kegiatan proyek tertentu. Berdasarkan hasil penelitian yang dilakukan Pratiwi (2010) dengan melakukan resitasi, siswa mempunyai kesempatan untuk saling membandingkan dengan hasil pekerjaan orang lain, dapat mempelajari dan mendalami hasil uraian orang lain, sehingga akan memperluas pengetahuan serta pengalaman siswa.

Investigate: pada tahap ini kegiatan pembelajaran memberikan kesempatan kepada siswa untuk melakukan investigasi secara bebas. Vygotsky (dalam Nur, 2000) menyatakan bahwa perkembangan intelektual terjadi pada saat individu berhadapan langsung dengan pengalaman baru yang menantang dan ketika berusaha untuk memecah masalah yang dimunculkan oleh pengalaman sendiri.Tahap ini terjadi kegiatan penetapan strategi melalui latihan, observasi dan transformasi pengalaman selama kegiatan pembelajaran. Tujuan dari tahap ini adalah untuk memberikan kebebasan pada siswa dalam menentukan cara maupun tindakan dalam menemukan solusi penyelesaian masalah.

Siswa pada tahap ini diajak melakukan investigasi melalui aktivitas berkomunikasi, yaitu mencari informasi, membaca referensi yang relevan dengan topik pembicaraan serta melakukan pengamatan.Investigasi melalui pengamatan secara rinci dan menilai secara sistematis memberikan kemungkinan siswa untuk mengembangkan pemahaman melalui berbagai kegiatan belajar dan hasil benar sesuai pengembangan yang dilalui siswa.Kegiatan ini dapat memberi siswa pengalaman fisik dan interaksi sosial.Pengalaman ini mendorong terjadinya konflik kognitif, dan menyebabkan siswa bertanya tentang konsep tertentu yang tidak sesuai dengan konsepsi awal.Belajar bermakna dapat terjadi jika konsep baru atau informasi baru dapat dikaitkan dengan konsep-konsep yang sudah ada dalam struktur kognitif siswa (Dahar, 2011). Mengonstruksi terus-menerus pengetahuan akan membuat terjadinya perubahan konsep yang lebih rinci serta sesuai dengan konsep ilmiah (Hanbury, 1996). Apabila terjadi konflik kognitif, maka siswa akan dapat menemukan pengetahuan baru. Semakin sempurna pengetahuan itu diproses, semakin baik peluang untuk mengingat informasi itu (Woolfolk, 2009).

Design plan project: pada tahap ini guru masih tetap melibatkan siswa pada proses, di mana siswa diminta untuk melakukan perancangan rencana proyek berdasarkan pengetahuan baru yang telah diperoleh pada tahap sebelumnya. Tujuan dari tahap ini adalah untuk memfasilitasi siswa membuat rencana proyek melalui penemuan prinsip kunci dari hasil investigasi, yang kemudian pengetahuan dimodifikasi dan dilaksanakan berdasarkan rencana yang telah dibuat.Perencanaan dilakukan secara kolaboratif antara guru dan siswa.Kerja proyek dapat memberikan penekanan pada penyelesaian masalah sebagai suatu usaha kolaboratif (Hung \& Wong, 2000).

Kegiatan perencanaan proyek ini siswa diarahkan pada kegiatan untuk mampu melakukan aktivitas berkomunikasi, yaitu menulis ilmiah melalui identifikasi dan pembuatan prosedur kerja.Setelah dibuat perencanaan kemudian dilakukan pelaksanaan kegiatan proyek.Kerja proyek dapat memberikan kesempatan bekerja secara mandiri (Thomas, 
1999).Dalam melaksanakan proyek tersebut, siswa harus menerapkan pengetahuan mereka untuk mengidentifikasi pertanyaan melalui penelitian, prosedur penyelidikan, desain produk, hasil pegumpulan dan analisis data dan membuat kesimpulan (Chen et al., 2011).Berdasarkan pelaksanaan kegiatan ini siswa diharapkan dapat membuat karya atau menemukan solusi menyelesaikan suatu masalah.

Discussion: pada tahap ini terjadi aktivitas guru dan siswa atau siswa dan siswa lainnya saling bercakap-cakap dan berbagi ide dan pendapat. Tujuan dari tahap ini adalah membentuk learning community dan pemahaman pengetahan ilmiah.Siswa lebih mudah menemukan dan memahami konsep-konsep yang sulit jika mereka saling mendiskusikan masalah tersebut (Slavin, 2006).Hal ini didukung pendapat Woolfolk (2009) yang menyatakan bahwa diskusi terbuka dengan siswa saling bertanya dan menjawab pertanyaan lebih baik dibanding kegiatan yang didominasi untuk mengembangkan argumen antar siswa. Kegiatan diskusi dan mengkritisi kelompok lain dapat membantu kelompok dalam menegosiasikan kriteria kesimpulan yang valid, meningkatkan pemahaman tentang konstruksi sosial dari pengetahuan ilmiah dan menciptakan community of learners, hal ini karena siswa tidak hanya membangun pengetahuan tetapi juga bekerja sama menciptakan lingkungan belajar (Sampson \& Gleim, 2009). Berdasarkan beberapa pendapat tersebut menunjukkan bahwa diskusi yang terjadi menekankan pada interaksi sosial di mana guru memfasilitasi siswa untuk melatihkan aktivitas berkomunikasi sains, yaitu presentasi dan representasi hasil proyek kepada siswa lainnya. Siswa akan mendapat informasi dan masukan yang bermanfaat dari kegiatan presentasi untuk memperbaiki hasil kinerjanya selama kegiatan proyek yang telah dilakukan. Sebagaimana pendapat Mayer (dalam Woolfolk, 2009) yang menjelaskan sebuah ide dengan kata-kata dan mempresentasikannya secara visual dalam bentuk gambar dan ilustrasi dapat membantu meningkatkan pemahaman tentang konsep sains. Ausubel (dalam Arends, 2007) menyatakan bahwa mempresentasikan berbagai ide dan informasi secara bermakna dan efektif akan menghasilkan makna yang jelas dan tidak ambigu sehingga berimplikasi pada tersimpannya ide tersebut dalam jangka yang lama dan terorganisasi. Implikasi dari kedua pendapat tersebut menunjukkan bahwa peran guru untuk mengelola kegiatan presentasi perlu mengarahkan siswa untuk menyajikan materi secara visual dan jelas, agar menghasilkan kebermaknaan dalam belajar.

Reflection: pada tahap ini guru dan siswa melakukan refleksi terhadap kegiatan proyek yang telah dilakukan. Istilah reflection ini juga mencerminkan kegiatan pemeriksaan dan perubahan perilaku. Dewey (dalam Arends, 2007) menyatakan bahwa berpikir reflektif dapat membantu siswa memperoleh keterampilan dan proses berpikir produktif. Kegiatan refleksi ini bertujuan untuk melakukan analisis dan evaluasi kegiata proyek serta mengetahui perasaan dan pengalaman siswa selama menyelesaikan proyek. Refleksi dapat membentuk proses mental yang mengaktifkan siswa untuk merangsang pemikiran kritis dalam menguji informasi yang didapat, bertanya tentang kebenaran dan menyimpulkan berdasarkan ide-ide yang dihasilkan (Ewell, 1997). Melalui tahap ini, guru dapat membantu siswa dengan pemodelan pemikiran reflektif dan mendukung siswa untuk mengevaluasi diri dan memikirkan hasil proyek dan strategi pembelajaran telah dilakukan. Berdasarkan pendapat tersebut maka dalam proses pembelajaran guru dan siswa dapat melakukan kegiatan refleksi dengan menggunakan diskusi untuk memperbaiki kinerja selama proses pembelajaran, sehingga melalui refleksi diharapkan dapat ditemukan suatu temuan baru untuk menjawab permasalahan.

Project fair: pada tahap ini pembelajaran dilakukan melalui kegiatan pameran hasil proyek sains kepada masyarakat. Pameran hasil karya dapat membantu siswa memahami 
kualitas hasil karya yang baik dan mengenali kualitas-kualitas tersebut dalam produk dan hasil karyanya (Woolfolk, 2009). Hasil penelitian menunjukkan bahwa kegiatan pameran proyek akan memberikan kesempatan bagi siswa untuk berlatih menyelidiki dan dapat berfungsi untuk memotivasi minat siswa dalam sains, mengembangkan keahlian dan keyakinan untuk penyelesaian masalah dan meningkatkan pemikiran kritis dan kemampuan belajar (Chen et al., 2011). Berdasarkan beberapa pendapat tersebut, pameran hasil proyek sains memiliki tujuan untuk menampilkan dan membantu siswa memahami kualitas hasil karya serta temuan dari proyek sains.

Tahapan pameran proyek ini sebenarnya hampir sama dengan tahap discussion, namun memiliki perbedaan dalam hal audiens dan cara penyajiannya. Audien yang dihadapi adalah masyarakat umum yang memiliki karakteristik dan pengetahuan yang berbeda.Hal ini menyebabkan siswa harus mampu untuk melakukan komunikasi yang efektif sesuai dengan pengetahuan masyarakat. Tahap ini terjadinya kegiatan komunikatif (dialog dan negosiasi) untuk mengetahui seberapa efektif proses penyelesaian masalah yang telah dilakukan, selain itu juga dapat berfungsi sebagai wahana penyampaian pengetahuan kepada masyarakat. Siswa juga dituntut untuk bisa fleksibel dalam menyampaikan pengetahuannya.Cara penyajian dalam pameran hasil proyek sains dapat dilakukan melalui berbagai media di antaranya seperti poster maupun gambar yang merepressentasikan hasil proyeknya. Peran guru pada tahap ini adalah untuk membimbing serta memberikan pemodelan cara berkomunikasi yang baik.

Demikian penjelasan tentang konstruksi teoritis model pembelajaran PRODUKSI, agar dapat diketahui kualitas dari model pembelajaran PRODUKSI maka perlu dilakukan validasi. Validasi ini bertujuan untuk melihat kualitas model yang dikembangkan. Joyce \& Showers (Arends, 2007) menyatakan bahwa dalam melakukan pengembangan model pembelajaran perlu untuk menekankan pada aspek: 1) sintaks (fase-fase pembelajaran); 2) sistem sosial, yang menekankan aspek kerjasama antara siswa dengan siswa dan siswa dengan guru secara bersungguh-sungguh melaksanakan aktivitas dalam pembelajaran; 3) prinsip pengelolaan/reaksi, menekankan aspek guru sebagai pemberi kemudahan atau fasilitator dalam proses pembelajaran di kelas; 4) dampak instruksional dan pengiring yang menekankan pencapaian dampak instruksional seperti keterampilan berpikir kreatif dan pemahaman konsep. Berdasarkan hal tersebut, maka aspek-aspek yang ditelaah pada pengembangan model pembelajaran adalah berdasarkan empat unsur tersebut.Hasil validasi model dapat disajikan pada tabel berikut ini.

Tabel 1. Hasil Validasi Model Pembelajaran PRODUKSI

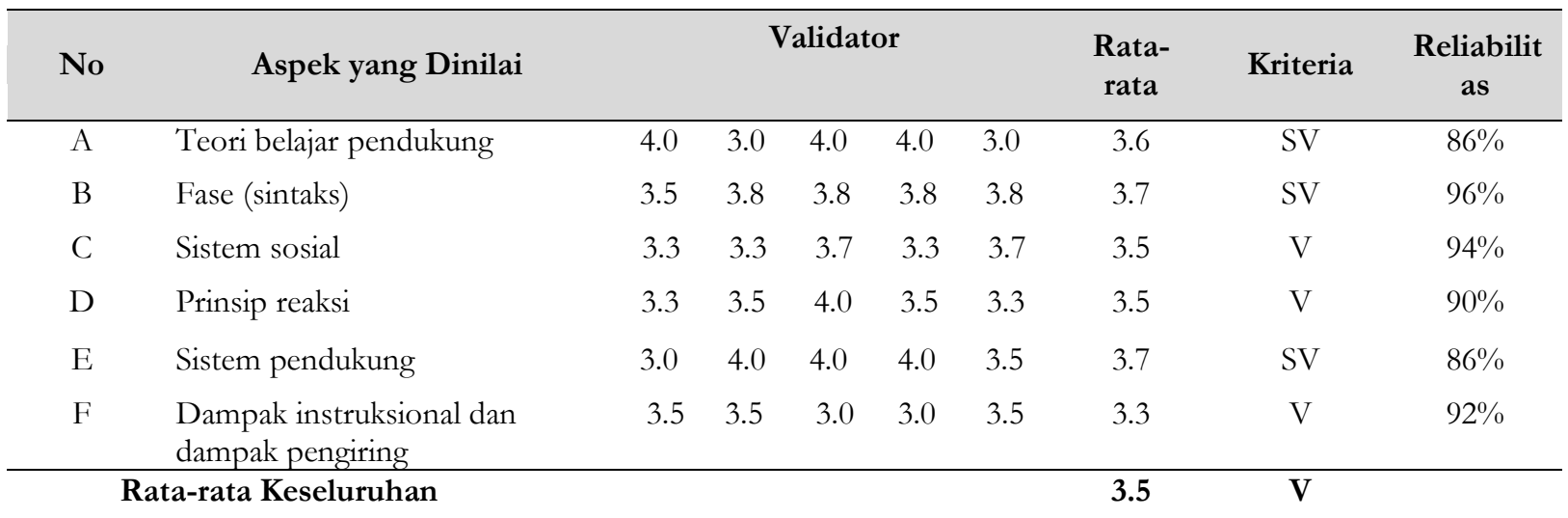


Tabel 1 diperoleh informasi bahwa model pembelajaran yang telah dikembangkan valid dan dapat diterapkan dalam pembelajaran dengan sedikit revisi.Reliabilitas pengamatan pada tiap aspeknya secara keseluruhan $\geq 75 \%$.Berdasarkan hasil validasi ditemukan bahwa model pembelajaran yang telah dikembangkan valid dan dapat diterapkan dalam pembelajaran dengan sedikit revisi.Aspek teori belajar pendukung diperoleh kriteria sangat valid, artinya model yang dikembangkan telah sangat sesuai dengan teori-teori yang dikemukakan terutama kesesuain dengan prinsip konstruktivis. Aspek sintaks pembelajaran diperoleh juga kategori sangat valid, hal ini menunjukkan bahwa fase yang dibuat logis, rasional, menggambarkan tujuan model, jelas dan dapat dilaksanakan.Aspek sistem sosial diperoleh kategori valid, fakta ini menunjukkan bahwa model pembelajaran yang telah dikembangkan dapat dengan baik memfasilitasi terjadinya interaksi siswa dengan guru, siswa dengan siswa.Aspek prinsip reaksi diperoleh kategori valid, berarti bahwa model pembelajaran yang dikembangkan baik untuk menstimulus siswa untuk berperilaku aktif, terampil, memiliki sikap positif dan menumbuhkan kemampuan berliterasi sains.Hasil penilaian pada aspek sistem pendukung berkategori sangat valid, hal ini menunjukkan bahwa model pembelajaran yang dikembangkan sangat baik dalam memfasilitasi siswa untuk memanfaatkan berbagai sumber belajar dan lingkungan belajar.

Model pembelajaran yang dihasilkan apabila telah teruji secara teoritis dan valid, maka sebagai pendukungnya dibuat perangkat pembelajaran dan instrumen penilaian yang diorientasikan pada model pembelajaran tersebut, yaitu model PRODUKSI. Perangkat tersebut terdiri dari RPP dan LKPD, serta intrumen penelitian yang meliputi lembar evaluasi dan penilaian.Selanjutnya, dilakukan validasi perangkat pembelajaran dan instrumen penelitian oleh ahli di bidang pendidikan sains/IPA, fisika, teknologi pembelajaran dan bahasa.Perangkat yang telah dikembangkan peneliti ditelaah dan divalidasi masing-masing oleh empat ahli yaitu di bidang pendidikan sains/IPA, fisika, teknologi pembelajaran dan bahasa.Validasi ini bertujuan untuk melihat kualitas perangkat yang dikembangkan. Aspek-aspek yang ditelaah disesuaikan dengan karakteristiknya

\section{Rencana Pelaksanaan Pembelajaran}

RPP merupakan pedoman yang dirancang secara sistematis, untuk menggambarkan skenario penyajian materi pembelajaran sesuai dengan fase model yang dikembangkan, yaitu model pembelajaran PRODUKSI. RPP yang dikembangkan adalah RPP berdasarkan acuan K13 pada kompetensi dasar menguasai fluida statis yang dirancang pada tiga kali pertemuan.RPP dirancang dengan pendekatan pembelajaran proyek yang menekankan kegiatan komunikasi. RPP yang dikembangkan memiliki bagian: 1) tujuan pembelajaran, 2) materi ajar, 3) metode pembelajaran, 4) skenario pembelajaran, dan 5) penilaian proses dan hasil belajar. RPP yang telah dikembangkan ini kemudian divalidasi oleh ahli di bidang pendidikan sains/IPA, fisika, teknologi pembelajaran dengan hasil seperti pada Tabel 2 berikut ini.

Tabel 2.Hasil Validasi RPP PRODUKSI

\begin{tabular}{clccccccc}
\hline No & \multicolumn{1}{c}{ Aspek yang dinilai } & $\mathbf{1}$ & $\mathbf{2}$ & $\mathbf{3}$ & $\mathbf{4}$ & $\begin{array}{l}\text { Rata- } \\
\text { rata }\end{array}$ & $\begin{array}{l}\text { krit } \\
\text { eria }\end{array}$ & $\begin{array}{l}\text { Reliabi } \\
\text { litas }\end{array}$ \\
\hline $\mathbf{A}$ & Tujuan Pembelajaran & $\mathbf{3 , 3}$ & $\mathbf{3 , 7}$ & $\mathbf{3 , 7}$ & $\mathbf{3 , 7}$ & $\mathbf{3 , 6}$ & SV & $\mathbf{9 4 \%}$ \\
1 & $\begin{array}{l}\text { Perumusan tujuan pembelajaran } \\
\text { operasional }\end{array}$ & 4 & 3 & 4 & 4 & & & \\
2 & & & & & & & \\
\hline & $\begin{array}{l}\text { Kejelasan perumusan tujuan } \\
\text { pembelajaran }\end{array}$ & 3 & 4 & 4 & 3 & & & \\
$\begin{array}{l}\text { Sesuai dengan karakteristik } \\
\text { pebelajar }\end{array}$ & 3 & 4 & 3 & 4 & & & \\
\hline
\end{tabular}




\begin{tabular}{|c|c|c|c|c|c|c|c|c|}
\hline \multirow{2}{*}{ No } & \multirow{2}{*}{ Aspek yang dinilai } & \multicolumn{4}{|c|}{ Validator } & \multirow{2}{*}{$\begin{array}{l}\text { Rata- } \\
\text { rata }\end{array}$} & \multirow{2}{*}{$\begin{array}{l}\text { krit } \\
\text { eria }\end{array}$} & \multirow{2}{*}{$\begin{array}{l}\text { Reliabi } \\
\text { litas }\end{array}$} \\
\hline & & 1 & 2 & 3 & 4 & & & \\
\hline B & Materi Ajar & 3,3 & 3,8 & 3,3 & 3,5 & 3,4 & $\mathbf{V}$ & $93 \%$ \\
\hline 4 & $\begin{array}{l}\text { Sesuai dengan kompetensi yang } \\
\text { harus dikuasai siswa }\end{array}$ & 3 & 4 & 3 & 4 & & & \\
\hline 5 & $\begin{array}{l}\text { Sesuai tingkat perkembangan } \\
\text { fisik, intelektual, emosional, } \\
\text { sosial, dan spritual siswa }\end{array}$ & 3 & 4 & 3 & 3 & & & \\
\hline 6 & Bermanfaat bagi siswa & 3 & 4 & 3 & 4 & & & \\
\hline 7 & $\begin{array}{l}\text { Mendorong siswa untuk } \\
\text { membangun pengetahuan } \\
\text { sendiri }\end{array}$ & 4 & 3 & 4 & 3 & & & \\
\hline $\mathrm{C}$ & Metode Pembelajaran & 3,3 & 3,0 & 3,7 & 3,7 & 3,4 & $\mathbf{V}$ & $90 \%$ \\
\hline 8 & $\begin{array}{l}\text { Menggunakan pendekatan } \\
\text { konstruktivis }\end{array}$ & 3 & 3 & 4 & 4 & & & \\
\hline 9 & $\begin{array}{l}\text { Kegiatan yang berpusat pada } \\
\text { siswa }\end{array}$ & 3 & 3 & 4 & 3 & & & \\
\hline 10 & $\begin{array}{l}\text { Menekankan pembelajaran yang } \\
\text { komunikatif }\end{array}$ & 4 & 3 & 3 & 4 & & & \\
\hline $\mathbf{D}$ & Kegiatan Pembelajaran & 3,5 & 3,5 & 3,7 & 3,5 & 3,6 & SV & $97 \%$ \\
\hline 11 & $\begin{array}{l}\text { Kejelasan skenario } \\
\text { pembelajaran (kegiatan } \\
\text { pendahuluan, inti, dan penutup) }\end{array}$ & 4 & 3 & 4 & 3 & & & \\
\hline 12 & $\begin{array}{l}\text { Skenario pembelajaran sesuai } \\
\text { dengan tujuan pembelajaran } \\
\text { yang dikembangkan }\end{array}$ & 4 & 4 & 3 & 4 & & & \\
\hline 13 & $\begin{array}{l}\text { Skenario pembelajaran sesuai } \\
\text { dengan model yang } \\
\text { dikembangkan }\end{array}$ & 3 & 3 & 4 & 4 & & & \\
\hline 14 & $\begin{array}{l}\text { Pengorganisasian skenario } \\
\text { pembelajaran sesuai dengan } \\
\text { alokasi waktu }\end{array}$ & 3 & 4 & 4 & 3 & & & \\
\hline $\mathbf{E}$ & Penilaian Hasil Belajar & 3,7 & 3,3 & 3,3 & 3,7 & 3,5 & $\mathbf{V}$ & $94 \%$ \\
\hline 15 & $\begin{array}{l}\text { Dapat mengukur ketercapaian } \\
\text { kompetensi siswa }\end{array}$ & 4 & 3 & 3 & 4 & & & \\
\hline 16 & Menggunakan acuan kriteria & 3 & 4 & 3 & 3 & & & \\
\hline 17 & $\begin{array}{l}\text { Sesuai dengan pengalaman } \\
\text { belajar yang ditempuh dalam } \\
\text { kegiatan pembelajaran }\end{array}$ & 4 & 3 & 4 & 4 & & & \\
\hline 18 & Sistem penilaian berkelanjutan & 4 & 4 & 3 & 3 & & & \\
\hline
\end{tabular}

Rata-rata Keseluruhan 3,5

Berdasarkan Tabel 2 diperoleh informasi bahwa RPP yang telah dikembangkan oleh peneliti memiliki kualitas dengan kategori valid dan dapat diterapkan dalam pembelajaran.Reliabilitas pengamatan pada tiap aspeknya secara keseluruhan $\geq 75 \%$. Hasil validasi menunjukkan bahwa RPP yang telah dikembangkan oleh peneliti memiliki kualitas dengan kategori valid.Aspek tujuan pembelajaran memperoleh kriteria sangat baik, artinya bahwa tujuan pembelajaran yang direncanakan adalah sangat operasional, spesifik, terukur, jelas, dan sesuai dengan karakteristik siswa.Aspek kegiatan pembelajaran memperoleh kriteria valid, hal ini menunjukkan bahwa perencanaan pada kegiatan pembelajaran baik 
secara format, memiliki kesesuaian dengan tujuan pembelajaran dan terorganisasi dengan baik.Pencapaian kualitas ini dikarenakan pengembangan perangkat ini telah melalui beberapa tahapan, yaitu analisis kebutuhan, analis siswa, analisis konsep, analisis tugas, dan diskusi dengan guru-guru fisika.Berdasarkan hasil validasi menunjukkan bahwa RPP yang telah dikembangkan peneliti layak diimplementasikan dalam pembelajaran fisika.

\section{Lembar Kegiatan Peserta Didik (LKPD)}

LKPD yang telah dikembangkan peneliti berorientasi proyek yang dirancang dengan mengutamakan aktivitas komunikatif.LKPD ini merupakan panduan siswa di dalam melakukan aktivitas penemuan solusi dari masalah yang diberikan. LKPD yang telah dikembangkan memiliki enam bagian utama, yaitu: 1) bagian masalah autentik, pada bagian ini siswa diberikan suatu permasalahan seputar fisika dalam bentuk cerita; 2) bagian penyelidikan masalah, pada bagian ini siswa diarahkan untuk mengdentifikasi masalah yang muncul pada soal cerita; 3) pencarian informasi, pada bagian ini siswa diarahkan untuk mencari informasi dari sumber belajar yang relevan; 4) jurnal catatan proyek, pada bagian ini siswa harus membuat catatan untuk mendukung kegiatan proyek dan gagasan solusinya; 5) rencana proyek, pada bagian ini siswa diminta untuk membuat rencana kegiatan berdasarkan solusi yang telah ditemukan; 6) refleksi, pada bagian ini siswa diarahkan untuk meninjau kembali rencana yang telah dibuat; 7) pembuatan model karya, pada bagian ini siswa diberikan ruang untuk berkarya sesuai dengan perencanaan proyek yang telah dibuat; dan 8) catatan lapangan, pada bagian terkahir ini siswa diminta untuk mencatat hasil seluruh kegiatannya. LKPD yang telah dikembangkan ini kemudian divalidasi oleh ahli di bidang Pendidikan IPA/Sains dan Fisika dengan hasil berikut ini.

Tabel 3.Hasil Validasi LKPD PRODUKSI

\begin{tabular}{|c|c|c|c|c|c|c|c|c|}
\hline \multirow{2}{*}{ No } & \multirow{2}{*}{$\begin{array}{r}\text { Aspek } \\
\text { yang Dinilai }\end{array}$} & \multicolumn{4}{|c|}{ Validator } & \multirow{2}{*}{ Rata-rata } & \multirow{2}{*}{ Kriteria } & \multirow{2}{*}{ Reliabilitas } \\
\hline & & 1 & 2 & 3 & 4 & & & \\
\hline $\mathrm{A}$ & \multirow{2}{*}{$\begin{array}{l}\text { Materi } \\
\text { Aktivita }\end{array}$} & 3.5 & 3.75 & 3.25 & 3.5 & 3.5 & $\mathrm{~V}$ & $93 \%$ \\
\hline B & & 3.5 & 3.5 & 3.5 & 4.0 & 3.6 & SV & $93 \%$ \\
\hline $\mathrm{C}$ & Bahasa & 3.0 & 3.5 & 3.5 & 3.5 & 3.4 & $\mathrm{~V}$ & $92 \%$ \\
\hline $\mathrm{D}$ & Waktu & 3.0 & 3.0 & 4.0 & 3.0 & 3.3 & $\mathrm{~V}$ & $86 \%$ \\
\hline \multicolumn{6}{|c|}{ Rata-rata Keseluruhan } & 3.4 & $\mathbf{V}$ & \\
\hline
\end{tabular}

Berdasarkan Tabel 3 diperoleh informasi bahwa LKPD yang telah dikembangkan peneliti valid dan dapat digunakan sebagai perangkat pembelajaran dengan sedikit revisi.Reliabilitas pengamatan pada tiap aspeknya secara keseluruhan $\geq 75 \%$. Berdasarkan hasil validasi diperoleh informasi bahwa LKPD yang telah dikembangkan oleh peneliti memiliki kualitas dengan kategori valid.Aspek materi memperoleh kriteria baik, artinya bahwa materi yang diberikan memiliki kesesuaian dengan indikator pembelajaran, kesesuaian dengan rumusan pertanyaan, serta kejelasan dalam pembuatan petunjuk pengerjaan dengan baik.Aspek aktivitas memperoleh kriteria sangat baik, hal ini menunjukkan bahwa aktivitas yang ditunjukkan telah sesuai dengan indikator pencapaian hasil belajar dan LKPD yang dibuat mampu untuk mewujudkan pembelajaran siswa aktif.Aspek bahasa berkategori baik, fakta ini menunjukkan bahwa kalimat yang digunakan jelas, mudah dimengerti dan sesuai dengan kaidah bahasa maupun fisika.Berdasarkan hasil validasi LKPD ini menunjukkan bahwa LKPD yang telah dikembangkan peneliti layak untuk diimplementasikan dalam mendukung aktivitas penyelesaian masalah fisika. 


\section{Lembar Evaluasi (LE)}

LE digunakan untuk mengukur keterampilan berkomunikasi sains siswa dan mengetahui ketercapaian tujuan pembelajaran. LE yang dikembangkan memiliki spesifikasi, yaitu: dalam bentuk soal uraian yang mengacu pada indikator dan deskriptor komunikasi sains yang dikembangkan oleh WPI (2008), AACL (2009), \& Beers (2003). Soal yang dikembangkan terdiri dari 12 soal, dengan rincian 7 soal berkaitan dengan kemampuan membaca, 1 soal menulis, 2 soal representasi, 1 soal presentasi dan 1 soal observasi. Adapun hasil penilaian LE adalah sebagai berikut.

Tabel 4.Hasil Validasi LE

\begin{tabular}{|c|c|c|c|c|c|c|c|c|}
\hline \multirow{2}{*}{ No } & \multirow{2}{*}{$\begin{array}{c}\text { Aspek yang } \\
\text { Dinilai }\end{array}$} & \multicolumn{4}{|c|}{ Validator } & \multirow{2}{*}{$\begin{array}{l}\text { Rata- } \\
\text { rata }\end{array}$} & \multirow{2}{*}{ Komentar } & \multirow{2}{*}{ Reliabilitas } \\
\hline & & 1 & 2 & 3 & 4 & & & \\
\hline A & Materi & 3.3 & 3.7 & 3.3 & 4.0 & 3.6 & SV & $90 \%$ \\
\hline B & Konstruksi & 3.5 & 3.5 & 3.3 & 3.3 & 3.4 & V & $97 \%$ \\
\hline $\mathrm{C}$ & Bahasa & 3.5 & 3.5 & 4.0 & 3.5 & 3.6 & SV & $93 \%$ \\
\hline & Rata-r & Kes & ru & & & 3.5 & $\mathbf{V}$ & \\
\hline
\end{tabular}

Berdasarkan Tabel 4 diperoleh informasi bahwa LE yang telah dikembangkan dapat digunakan sebagai perangkat pembelajaran dengan sedikit revisi.Reliabilitas pengamatan pada tiap aspeknya secara keseluruhan $\geq 75 \%$. Hasil validasi diperoleh informasi bahwa LE yang telah dikembangkan oleh peneliti memiliki kualitas dengan kategori valid.Aspek materi memperoleh kriteria valid, artinya bahwa butir soal yang diberikan memiliki kesesuaian dengan indikator pembelajaran dan jenjang pendidikan. Aspek konten memperoleh kriteria baik, hal ini menunjukkan bahwa isi yang ditunjukkan jelas, tegas, butir tidak bergantung satu sama lain, serta simbol-simbol yang disajikan berfungsi dan berhubungan dengan masalah yang ditanyakan. Aspek bahasa berkategori baik, fakta ini menunjukkan bahwa kalimat yang digunakan komunikatif, mudah dimengerti dan sesuai dengan kaidah bahasa maupun fisika.Berdasarkan hasil validasi dan uji coba LE menunjukkan bahwa LE yang dikembangkan layak untuk diimplementasikan untuk mengukur keterampilan berkomunikasi sains.

\section{Lembar Penilaian (LP)}

LP dikembangkan dalam bentuk soal uraian yang mengacu pada indikator komunikasi sains yang dikembangkan oleh WPI (2008), AACL (2009), \& Beers (2003).Agar ciri-ciri ini dapat diamati dalam kegiatan pembelajaran, maka peneliti mengembangkan diskripsi operasional (kriteria) masing-masing ciri tersebut.LP ini dikembangkan dengan memadukan lembar pengamatan metode rating scale tipe checlist dan lembar pengamatan metode coding system.Hasil penilaian LP adalah sebagai berikut.

Tabel 5. Hasil Validasi LP

\begin{tabular}{|c|c|c|c|c|c|c|c|c|}
\hline \multirow{2}{*}{$\begin{array}{l}\mathbf{N} \\
\mathrm{A}\end{array}$} & $\begin{array}{c}\text { Aspek yang } \\
\text { dinilai }\end{array}$ & \multicolumn{4}{|c|}{ Validator } & $\begin{array}{c}\text { Rata- } \\
\text { rata }\end{array}$ & Komentar & Reliabilitas \\
\hline & Format & 3.4 & 3.2 & 3.2 & 3.6 & 3.4 & V & $94 \%$ \\
\hline B & Isi & 3.5 & 3.5 & 4 & 3.5 & 3.6 & SV & $93 \%$ \\
\hline $\mathrm{C}$ & Bahasa & 3.5 & 3.3 & 3.3 & 3.5 & 3.4 & $\mathrm{~V}$ & $97 \%$ \\
\hline & Rata & ta Ke & elur & ian & & 3.5 & $\mathbf{V}$ & \\
\hline
\end{tabular}


Berdasarkan Tabel 5 diperoleh informasi bahwa LP yang telah dikembangkan valid dan dapat digunakan sebagai perangkat pembelajaran dengan sedikit revisi.Reliabilitas pengamatan pada tiap aspeknya secara keseluruhan $\geq 75 \%$.Berdasarkan hasil validasi diperoleh informasi bahwa LP yang dikembangkan oleh peneliti memiliki kualitas dengan kategori valid.Pada aspek format memperoleh kriteria valid, artinya jelas dan dapat dengan mudah digunakan.Pada aspek isi memperoleh kriteria valid, hal ini menunjukkan bahwa isi yang disajikan sesuai dengan indikator dan aspek keterampilan berkomunikasi sains.Aspek bahasa berkategori valid, hasil ini menunjukkan bahwa kalimat yang digunakan komunikatif, mudah dimengerti dan sesuai dengan kaidah bahasa maupun fisika.Berdasarkan hasil validasi menunjukkan bahwa LE yang dikembangkan peneliti layak digunakan untuk menilai keterampilan berkomunikasi sains.

\section{SIMPULAN}

Model yang dikembangkan merupakan bentuk produk transdisipliner, yaitu produk yang diperoleh dari kajian bidang ilmu yang diintegrasikan satu sama lain yang menghasilkan ilmu baru. Produk yang dihasilkan adalah model pembelajaran fisika dan diberi nama "PRODUKSI" yang merupakan akronim dari pendekatan pembelajarannya, yaitu "pembelajaran berbasis proyek yang diorientasikan menggunakan keterampilan berkomunikasi". Fase model pembelajaran PRODUKSI meliputi: 1)menyajikan masalah esensial (essential problem), 2) melakukan resitasi (recitation), 3)melakukan pengamatan dan penyelidikan (investigate), 4)membuat perencanaan proyek (design plan project), 5)melaksanakan proyek dan refleksi kegiatan (reflection), 6)mendiskusikan hasil kegiatan proyek (discussion), dan 7) melakukan pameran hasil proyek (project fair). Berdasarkan hasil penilaian ahli dapat disimpulkan jika model yang telah dikembangkan (model PRODUKSI) secara konstruksi valid dan layak diimplementasikan dalam pembelajaran yang berkarakteristik scientific approach sesuai dengan rekomendasi K13, dan perangkat pendukungnya berupa RPP, LKPD, LE dan LP secara konten valid dan layak diimplementasikan dalam pembelajaran fisika, mendukung aktivitas proyek serta penyelesaian masalah fisika, dan mampu mengembangkan salah satu keterampilan abad 21 yaitu keterampilan berkomunikasi sains.

\section{DAFTAR PUSTAKA}

Arends, R. I. (2007). Learning to teach: jilid dua (terjemahan). Yogyakarta: Pustaka Pelajar.

Beers, K. (2003). When Kids Can't Read. Diunduh Januari 3, 2013, dari http://www.nald.ca/clr/btg/ed/evaluation/reading.htm

Chen, J. J., Lin, H. S., Hsu, Y. S., \& Lee, H. (2011). Data and claim the refinement of science fair work through argumentation. International Journal of Science Education, Part $B, 1,147-164$.

Cohen, R. J., \& Swerdik, M. E. (2010).Psychological testing and assessment. 7th ed. Singapore: McGraw-Hill International Edition.

Dahar, R. W. (2011). Teori-teori belajar dan pembelajaran. Jakarta: Erlangga.

Ewell, P. T. (1997). Organizing for Learning: A point of entr.draft prepared for discussion at the 1997 AAHE Summer academy at snowbird. New York: National Center for Higher Education Management Systems (NCHEMS). 
Gallagher, S. S., Stepien, W. J., Sher, B. T., \& Workman, D. (1995). Implementing problem based learning in science classroom. Scholl Science and Mathematic, 95, 136-146.

Hanbury, L. (1996). Constructivism: so what? Melbourne: The Mathematical Assciation of Victoria.

Hung, D. W., \& Wong, A. F. (2000).Activity theory as a framework for project work in learning environment.Educational Technology, 40, 30-37.

Nur, M. (2000).Buku panduan keterampilan proses dan hakekat sains. Surabaya: University Press UNESA.

Pratiwi, D. A. (2010).Pembelajaran berbasis masalah (problem based learning) dengan metode proyek dan resitasi ditinjau dari kreativitas dan konsep diri (self concept) siswa.Program Pascasarjana Universitas Sebelas Maret Surakarta.Tesis tidak diterbitkan.

Sampson, V., \& Gleim, L. (2009).Argument-driven Inquiry to promote the understanding of important concepts and practices in biology. The American Biology Teacher, 71, 471477.

Slavin, R. (2006). Educational psychology theory and practice sixth edition. Boston: Allyn and Bacon.

Thomas, J. W. (1999). Project Based Learning: A handbook of middle and bigh school teacher. Novato CA: The Buck Institute For Education.

Treise, D., \& Weigold, M. F. (2002).Advancing science communication: A survey of science communicators. Science Communication, 23, 310-322.

Woolfolk, A. (2009). Educational psychology: Bagian Kedua. Boston: Pearson Education.

WPI.(2008). Writing, reading, and presentation rubric. Massachusetts: Massachusetts Academy of Mathematics and Science.

Yalcin, A. U., Turgut, \& Buyukkasap, E. (2009). The effect of project based learning on science undergraduate's learning of electricity, attitude toward physics and scientific process skills. International Online Journal of Educational Science, 1, 81-105. 